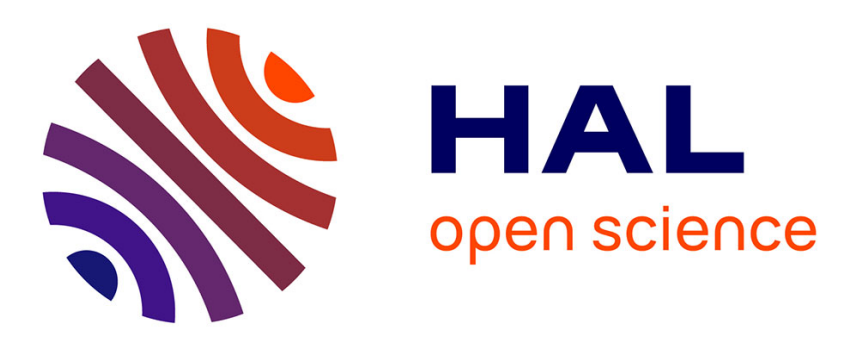

\title{
Monodispersed MOF-808 Nanocrystals Synthesized via a Scalable Room-Temperature Approach for Efficient Heterogeneous Peptide Bond Hydrolysis
}

\author{
Shan Dai, Charlotte Simms, Iurii Dovgaliuk, Gilles Patriarche, Antoine
} Tissot, Tatjana N Parac-Vogt, Christian Serre

\section{To cite this version:}

Shan Dai, Charlotte Simms, Iurii Dovgaliuk, Gilles Patriarche, Antoine Tissot, et al.. Monodispersed MOF-808 Nanocrystals Synthesized via a Scalable Room-Temperature Approach for Efficient Heterogeneous Peptide Bond Hydrolysis. Chemistry of Materials, 2021, 33 (17), pp.7057-7066. 10.1021/acs.chemmater.1c02174 . hal-03403603

\section{HAL Id: hal-03403603 \\ https://hal.science/hal-03403603}

Submitted on 26 Oct 2021

HAL is a multi-disciplinary open access archive for the deposit and dissemination of scientific research documents, whether they are published or not. The documents may come from teaching and research institutions in France or abroad, or from public or private research centers.
L'archive ouverte pluridisciplinaire HAL, est destinée au dépôt et à la diffusion de documents scientifiques de niveau recherche, publiés ou non, émanant des établissements d'enseignement et de recherche français ou étrangers, des laboratoires publics ou privés. 


\section{Monodispersed MOF-808 nanocrystals synthesized}

\section{via scalable room-temperature approach for efficient heterogeneous peptide bond hydrolysis}

Shan Dai, ${ }^{1}$ Charlotte Simms, ${ }^{2}$ Iurii Dovgaliuk, ${ }^{1}$ Gilles Patriarche, ${ }^{3}$ Antoine Tissot, ${ }^{1 *}$ Tatjana N.

Parac-Vogt, ${ }^{2 *}$ Christian Serre ${ }^{1 *}$

1 Institut des Matériaux Poreux de Paris, Ecole Normale Supérieure, ESPCI Paris, CNRS, PSL University, 75005 Paris, France

2 Department of Chemistry, KU Leuven, Celestijnenlaan 200F, 3001 Leuven, Belgium

3 Université Paris-Saclay, CNRS, Centre de Nanosciences et de Nanotechnologies, 91120 Palaiseau, France

E-mail: antoine.tissot@ens.psl.eu, tatjana.vogt@kuleuven.be, christian.serre@ens.psl.eu 


\begin{abstract}
:
$\mathrm{Zr}(\mathrm{IV})$-based metal-organic frameworks (MOFs) such as the $\mathrm{Zr}(\mathrm{IV}$ ) trimesate MOF-808 are promising materials for catalytic applications. In this work, we report an aqueous solution-based room temperature strategy to produce well-defined monodispersed MOF-808 nanocrystals down to $35 \mathrm{~nm}$ with a high space-time yield, up to $2516 \mathrm{~g} / \mathrm{m}^{3} /$ day, and an excellent crystallinity and porosity. The resulting nanocrystals show remarkable colloidal dispersion during one day in a wide range of nanoparticles concentrations. As a result, $35 \mathrm{~nm}$ MOF-808 colloidal-level nanocrystals exhibit the highest rate of selective peptide bond and protein hydrolysis among reported $\mathrm{Zr}(\mathrm{IV})$-based MOFs. This result may open new opportunities for highly efficient peptide or protein hydrolysis using scalable nano-catalyst.
\end{abstract}




\section{Introduction}

In the past decades, nanotechnology has generated interest in many fields, including bioapplications, ${ }^{1}$ sensing ${ }^{2}$ and catalysis. ${ }^{3}$ Metal-Organic Frameworks (MOFs) are ordered hybrid porous materials that are promising for a wide scope of potential applications, ${ }^{4-7}$ including new properties upon downsizing. ${ }^{8-10}$ Nano-MOFs are particularly appealing in catalysis for their highly tunable porosity and reactivity (presence of acid/basic sites, redox active cations...) that can even sometimes surpass previously studied nanomaterials. ${ }^{11}$ However, formulation of MOFs as high quality nanomaterials has been relatively underdeveloped despite a few well-developed strategies (e.g., microwave, ${ }^{12}$ modulating chemical, ${ }^{13}$ spray-drying ${ }^{14}$ ). Often, the produced nanoMOFs are lacking in uniformity, crystallinity/porosity and even more frequently, are obtained without size control. ${ }^{15,16}$ Thus, the development of new high quality MOF nanomaterials with controllable size may open some new perspectives for catalysis. For example, one emerging application for MOFs is their potential use as artificial nanozymes for middle down proteomics. For accurate protein fragment identification via mass spectrometry, proteins require partial breakdown into smaller fragments, which is achieved through hydrolysis of the highly stable peptide bond $(\mathrm{t} 1 / 2 \sim 400$ years $) .{ }^{17}$ It has been shown that peptide bond hydrolysis can be catalyzed by some metal salts that can however be prone to hydro-gel formation when used in physiological conditions. ${ }^{18-22}$ This problem can be overcome through incorporation of the active metal salts into soluble complexes or MOF materials. A few MOFs have already been proven to be active towards hydrolysis of peptide bonds in a range of dipeptides and proteins. ${ }^{23-25}$ In addition, they are more cost effective than traditional enzymatic methods due to their stability 
and reusability. Therefore, nanoMOFs are highly promising for the development of extremely efficient catalysts to produce peptides suitable for middle down proteomics.

$\mathrm{Zr}(\mathrm{IV})$-carboxylate based MOFs are known as a subclass of MOFs that usually provide high chemical robustness. ${ }^{26}$ A prominent example, UiO-66 (University of Oslo), was first reported in 2008 by Lillerud and co-workers and later studied for many potential applications. ${ }^{27-29}$ MOF-808 is another benchmark solid that is promising for catalytic applications, where the trimesate linker is used to bridge $\mathrm{Zr}_{6}$ oxoclusters with a molar-ratio of $2: 1$ to give a cubic structure with potentially unsaturated coordination sites, high BET surface area $\left(2060 \mathrm{~m}^{2} / \mathrm{g}\right)$ and a large pore size $(18.4 \AA) .{ }^{30-32}$ Synthesizing $\mathrm{Zr}(\mathrm{IV})$-based MOFs mostly relies on solvothermal strategies using toxic solvents (e.g. DMF), which is not an environmentally-friendly method and is not suitable for some applications such as the synthesis of host-guest architectures using the bottlearound-ship approach. ${ }^{33,34}$ Nonetheless, a few pioneering works have reported the room temperature (RT) synthesis of $\mathrm{Zr}(\mathrm{IV})$-carboxylate based MOFs but most of these attempts were dedicated to 12-connected (each metal cluster coordinated to 12 organic linkers) UiO-type MOFs and the use of DMF was often inevitable. ${ }^{35-41}$ Considering the appealing properties of MOF-808 and its use in several well-documented advanced applications, ${ }^{31}$ developing an approach to produce MOF-808 nanocrystals at room temperature using environmentally friendly conditions appears really promising.

Herein, we report a two-step, room temperature approach for the synthesis of MOF-808 in environmentally friendly conditions. The MOF nucleation-growth kinetics was investigated by in-situ powder X-ray diffraction (PXRD), which facilitated the understanding of the MOF synthesis. Tuning the synthesis conditions allowed us to obtain monodisperse MOF crystals from sub-micron scale $(850 \mathrm{~nm})$ down to the nanoscale $(35 \mathrm{~nm})$ via a concentration-induced method, 
which simultaneously enabled a space-time yield (STY) reaching $2516 \mathrm{~kg} / \mathrm{m}^{3} /$ day for the smallest nano-MOF-808. To the best of our knowledge, this is the first study tuning the crystal size of MOF-808 with such a high yield at room temperature. Finally, we demonstrated not only the high long-term colloidal stability of the synthesized nano-MOF-808 in a large concentration range but also the effect of particle's size on the efficiency of the highly selective peptide bond hydrolysis in a Hen Egg White Lysozyme (HEWL) protein by MOF-808. Notably, the remarkable catalytic efficiency of nano-MOF-808 allows us to obtain protein fragments of suitable size, which are in the range for the analysis in the emerging middle-down proteomic applications.

\section{Experimental}

All chemicals were purchased from commercial suppliers and used as received without further purification. Trimesic acid, 98\%, Alfa Aesar. $\mathrm{ZrCl}_{4}$ anhydrous, 98\%, Acros. Zirconyl chloride octahydrate, 98\%, Acros. Isopropyl alcohol, 99+\%, Sigma. Formic acid, 98\%, Acros. Acetic acid, 99+\%, Fisher. Acetone, 99\%, Acros. Ethanol absolute, >=99\%, Acros. Distilled water, Millipore system.

\section{Synthesis of $\mathrm{Zr}_{6}$ oxoclusters:}

$\mathrm{ZrCl}_{4}(200 \mathrm{~g}, 0.84 \mathrm{~mol})$ was added in a mixture of $300 \mathrm{~mL}$ of acetic acid and $500 \mathrm{~mL}$ of isopropanol under stirring at $500 \mathrm{rpm}$ and heated at $120{ }^{\circ} \mathrm{C}$ for $60 \mathrm{~min}$. The product was collected either through suction filtration or centrifugation at $10000 \mathrm{rpm}$. The collected white solid was subsequently washed with acetone twice and dried under vacuum at room temperature. The dry powder mass was $175 \mathrm{~g}$, corresponding to $98 \%$ of product yield (calculation based on the $\mathrm{Zr}$ salt) and to a space-time yield of $5340 \mathrm{~kg} / \mathrm{m}^{3} /$ day. 


\section{Synthesis of MOF-808:}

MOF-808-DMF: MOF-808 was obtained via solvothermal synthesis in N,N-dimethylformamide

(DMF) at $110^{\circ} \mathrm{C}$ for 48 hours using a method adapted from literature. ${ }^{30}$ Typically, $1,3,5-$ benzenetricarboxylic acid $(1.49 \mathrm{~g}, 7 \mathrm{mmol})$ was added to $\mathrm{N}, \mathrm{N}$-dimethylformamide $(128 \mathrm{~mL})$ in a thick glass jar while stirring at $600 \mathrm{rpm} . \mathrm{ZrOCl}_{2} \cdot 8 \mathrm{H}_{2} \mathrm{O}(2.16 \mathrm{~g}, 6.7 \mathrm{mmol})$ and formic acid (133 $\mathrm{mL}$ ) were subsequently added and the reaction mixture was stirred 20 minutes at room temperature. The jar was then heated at $110^{\circ} \mathrm{C}$ for 48 hours. A white solid was collected by centrifugation at $14500 \mathrm{rpm}$ for 5 minutes and washed in $\mathrm{N}, \mathrm{N}$-dimethylformamide $(250 \mathrm{~mL})$ at $100{ }^{\circ} \mathrm{C}$ overnight under stirring at $350 \mathrm{rpm}$. The solid was collected again by centrifugation and further washed in acetone $(250 \mathrm{~mL})$ at $60{ }^{\circ} \mathrm{C}$ overnight under stirring at $600 \mathrm{rpm}$. The solid was finally collected by filtration and dried in air.

$850 \mathrm{~nm}$ MOF-808: $\mathrm{Zr}_{6}$ oxoclusters $(0.6 \mathrm{~g})$ was dispersed in formic acid $(3 \mathrm{~mL})$ under stirring at $600 \mathrm{rpm} . \mathrm{H}_{2} \mathrm{O}(5 \mathrm{~mL})$ was subsequently added and the reaction mixture was stirred until being completely colorless. 1,3,5-Benzenetricarboxylic acid (150 mg, $0.7 \mathrm{mmol})$ was then added and the reaction was stirred overnight. The solid was collected by centrifugation at $14500 \mathrm{rpm}$ for 5 minutes and then simply washed with $40 \mathrm{~mL}$ of $\mathrm{H}_{2} \mathrm{O}$ and $40 \mathrm{~mL}$ of EtOH once, respectively. The collected solid was dried in vacuum for 3 hours affording a white powder.

$210 \mathrm{~nm}$ MOF-808: A similar procedure as for $850 \mathrm{~nm}$ MOF-808 was used with solvent volumes divided by 2 (1.5 $\mathrm{mL}$ of formic acid and $2.5 \mathrm{~mL}$ of $\left.\mathrm{H}_{2} \mathrm{O}\right)$.

60 nm MOF-808: A similar procedure as for $850 \mathrm{~nm}$ MOF-808 was used with solvent volumes divided by 4 (0.75 $\mathrm{mL}$ of formic acid and $1.25 \mathrm{~mL}$ of $\left.\mathrm{H}_{2} \mathrm{O}\right)$.

35 nm MOF-808: $\mathrm{Zr}_{6}$ oxoclusters $(1.2 \mathrm{~g})$ was dispersed in formic acid $(1 \mathrm{~mL})$ under stirring at $600 \mathrm{rpm} . \mathrm{H}_{2} \mathrm{O}(1.67 \mathrm{~mL})$ was subsequently added and the reaction mixture was stirred until 
being completely colorless. 1,3,5-Benzenetricarboxylic acid (300 mg, $1.4 \mathrm{mmol})$ was then added and the reaction was stirred for $5 \mathrm{~h}$. The solid was collected by centrifugation at $14500 \mathrm{rpm}$ for 60 minutes and then simply washed with $40 \mathrm{~mL}$ of $\mathrm{H}_{2} \mathrm{O}$ and $40 \mathrm{~mL}$ of EtOH once, respectively. The collected solid was dried in vacuum for 3 hours affording a white powder.

MOF activation for hydrolysis reaction: Prior to being used as catalyst for peptide and protein hydrolysis, MOFs were activated in batches of $50 \mathrm{mg}$ in $0.5 \mathrm{M} \mathrm{HCl}$ - acetone solution for $72 \mathrm{~h} \mathrm{(3}$ x $2 \mathrm{~mL})$ and methanol for $24 \mathrm{~h}(2 \times 2 \mathrm{~mL})$. After that, the MOFs were dried at $70^{\circ} \mathrm{C}$ for $2 \mathrm{~h}$ and activated at $160^{\circ} \mathrm{C}$ for $24 \mathrm{~h}$ at atmospheric pressure.

Glycylglycine hydrolysis: For each experiment, $2 \mu \mathrm{mol}$ of MOF and $1 \mathrm{~mL}$ of glycylglycine (GG) in $\mathrm{D}_{2} \mathrm{O}(2 \mathrm{mM})$ were mixed and $\mathrm{pD}$ was adjusted with $\mathrm{NaOD}$ and $\mathrm{DCl}$ to $\mathrm{pD}$ 7.6. Each sample was incubated at $60{ }^{\circ} \mathrm{C}$ for $20 \mathrm{~h} .600 \mu \mathrm{L}$ aliquots were taken at different time points, centrifuged and the resulting supernatant, to which internal standard TMSP- $\mathrm{d}_{4}$ was added, was analyzed with ${ }^{1} \mathrm{H}$ NMR (Bruker $300 \mathrm{MHz}, 32$ scans, Topspin 4.0.8 software).

Protein hydrolysis: $0.1 \mathrm{mM}$ protein solution $(1 \mathrm{~mL})$ was mixed with $2 \mu \mathrm{mol}$ MOF and incubated at $60{ }^{\circ} \mathrm{C}$ at $\mathrm{pH} 7.2$ for $72 \mathrm{~h} .100 \mu \mathrm{L}$ aliquots were taken for each time point, and analyzed with sodium dodecyl sulfate polyacrylamide gel electrophoresis (SDS-PAGE).

Electrophoresis: SDS-PAGE was performed with a $0.5 \mathrm{M}$ Tris - $\mathrm{HCl}$ buffer (pH 6.8) 4\% (w/v) polyacrylamide stacking gel and a $1.5 \mathrm{M}$ Tris - $\mathrm{HCl}$ buffer $(\mathrm{pH} 8.8) 16 \%(\mathrm{w} / \mathrm{v})$ polyacrylamide resolving gel. $15 \mu \mathrm{L}$ of reaction mixture and $5 \mu \mathrm{L}$ of buffer were combined and incubated at $95^{\circ} \mathrm{C}$ for 5 min prior to the loading of $10 \mu \mathrm{L}$ into gel wells. Page Ruler unstained low range protein ladder was used as the molecular weight standard, and gels were run at $200 \mathrm{~V}$ for $2 \mathrm{~h}$. Subsequently, the gels were stained with Coomassie Blue and imaged with a Gel Doc EZ Imager and Bio-Rad Image Lab software. 


\section{Results and discussion}

In the MOF-808 framework, $\mathrm{Zr}_{6}$-nodes are at the vertices and trimesate linkers at the faces of a tetrahedral cage with internal pore size of $4.8 \AA$. Ten contiguous tetrahedral cages are assembled to form a large adamantane cage with an inner diameter of $18.4 \AA$ (Figure 1a) assembled in a spn topology. The room temperature synthesis of MOF-808 was performed using preformed octahedral $\mathrm{Zr}_{6}$ oxoclusters, which is the most common SBU (secondary building unit) in the family of $\mathrm{Zr}(\mathrm{IV})$-carboxylate based MOFs. The synthesis of the $\mathrm{Zr}_{6}$ oxoclusters was carried out by using a scalable reflux method in a mixture of isopropyl alcohol and acetic acid at $100{ }^{\circ} \mathrm{C}$ during $1 \mathrm{~h}$. In order to confirm the composition of the obtained species, ESI-MS (electrospray ionization mass spectroscopy) was applied. As shown in Figure S3, the spectrum pattern observed from solution evidenced the presence of $\mathrm{Zr}_{6}$ oxoclusters, with an average formula of $\mathrm{Zr}_{6} \mathrm{O}_{4}(\mathrm{OH})_{4}\left(\mathrm{C}_{2} \mathrm{H}_{3} \mathrm{O}_{2}\right)_{8}\left(\mathrm{H}_{2} \mathrm{O}\right)_{2} \mathrm{Cl}_{3}$ that is consistent with the atomic ratio $(67 \% / 33 \%)$ between $\mathrm{Zr} / \mathrm{Cl}$ obtained from EDX (Energy-dispersive X-ray spectroscopy, see Figure S1). The efficient preparation of $\mathrm{Zr}_{6}$ oxoclusters was performed with a high space-time yield $\left(\sim 5340 \mathrm{~kg} / \mathrm{m}^{3} /\right.$ day $)$ compatible with up-scaled synthesis (>100 g). From a lab-scale point of view, we demonstrated (Figure S2) that these $\mathrm{Zr}_{6}$ acetate oxoclusters can be synthesized either on a small or large scale $(100 \mathrm{~g})$ without any drop in yield and quality. This new environmentally friendly preparation of $\mathrm{Zr}_{6}$ oxoclusters with high STY surpassed the previously reported ones that were either performed in toxic solvents or present limited scalability. ${ }^{36,40}$ MOF-808 synthesis was then performed by simply mixing $\mathrm{Zr}_{6}$ oxoclusters with formic acid, water and BTC (trimesic acid) under stirring at $600 \mathrm{rpm}$. The alternative use of acetic acid led to completely clear solution without any product after 7 days at room temperature and therefore, formic acid was used for all the synthesis in this 
work. After $18 \mathrm{~h}$ of stirring, the appearance of a white slurry indicated the formation of MOF808-RT (RT: Room Temperature). The synthesis yield was calculated based on the amount of ligand, reaching almost $100 \%$. After washing with water and ethanol once respectively, powder X-ray diffraction (PXRD) (Figure 1b) demonstrated the successful synthesis of highly crystalline MOF-808 by comparison to the simulated diffraction pattern. Taking into account the ease of the washing step, this water-based green synthesis has a great advantage in comparison to the DMF-based one, where 10 days are needed to fully activate the MOF. ${ }^{30,42}$
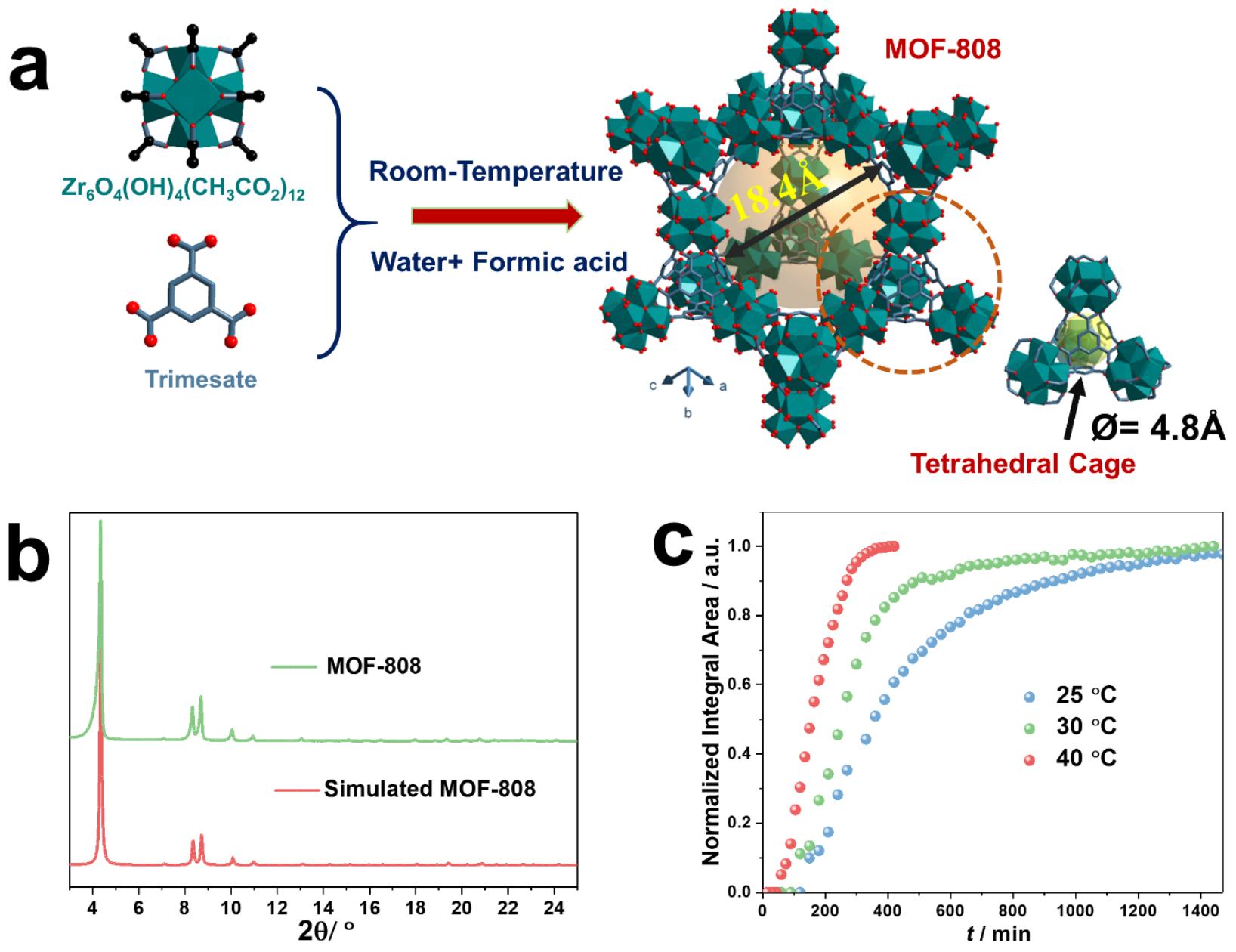

Figure 1. (a) Structures of $\mathrm{Zr}_{6} \mathrm{O}_{4}(\mathrm{OH})_{4}\left(\mathrm{CH}_{3} \mathrm{CO}_{2}\right)_{12}$ nodes, trimesate linker, and the MOF-808 (tetrahedral and adamantine-shaped cages); (b) PXRD $(\lambda \mathrm{Cu}=1.5406 \AA)$ pattern of MOF-808 and the corresponding simulated PXRD pattern; (c) Normalized integral intensities of (3 11 1) Bragg reflection as a function of time $(\mathrm{t})$ for different temperatures. 
MOF-808-RT displayed a typical $\mathrm{N}_{2}$ sorption isotherm at $77 \mathrm{~K}$ (Figure S4) with a high $\mathrm{N}_{2}$ adsorption capacity of $512 \mathrm{~cm}^{3} / \mathrm{g}$ along with a high Brunauer-Emmett-Teller (BET) surface area $\left(2090 \pm 17 \mathrm{~m}^{2} / \mathrm{g}\right)$, which matches very well with the reported value $\left(2060 \mathrm{~m}^{2} / \mathrm{g}\right){ }^{30}$ The pore size of MOF-808-DMF, which was calculated using density functional theory (DFT) on a sample prepared using the reported synthesis in DMF, showed two types of apertures at ca. $6.5 \AA$ and 15.5 $\AA$, corresponding to the windows of the tetrahedral and adamantane-shaped cages respectively (Figure S5). In the case of MOF-808-RT, the peak at $6.5 \AA$ was not observed, whereas the large pore shifted to $18.6 \AA$ and an additional new peak at $12.5 \AA$ was detected, suggesting very likely the presence of low temperature-induced defects (LTID). ${ }^{41}$ Infrared spectra (IR) (Figure S6) evidenced the absence of a $\mathrm{C}=\mathrm{O}$ stretching band at around $1700 \mathrm{~cm}^{-1}$ corresponding to uncoordinated $\mathrm{COOH}$ groups- in the washed MOF-808-RT solid, suggesting that the compound does not present missing nodes. Thermogravimetric analysis (TGA) (Figure S7) proved that each $\mathrm{Zr}_{6}$ node of MOF-808-RT is connected to 1.82 trimesate ligands, compared to 2 for the defectless structure, suggesting that $9 \%$ of linkers are missing, which might explain the slightly increased pore size compared to the ideal structure.

In order to shed light on the crystallization process, we performed in-situ diffraction measurements using a laboratory X-ray powder diffractometer in order to get a quantitative insight into the nucleation kinetics (e.g., activation energy, reaction rate). ${ }^{43}, 44$ The reaction kinetics has been studied at $25^{\circ} \mathrm{C}, 30{ }^{\circ} \mathrm{C}$ and $40{ }^{\circ} \mathrm{C}$, respectively. Notably, such temperaturedependent in-situ kinetic studies were usually restricted to hydro/ solvo-thermal synthesis and therefore relying on the use of synchrotron pressure-resistant systems. Here, the ambient conditions and relatively fast kinetics allowed us to investigate the thermal kinetics of a MOF material using a laboratory diffractometer. Figure S8 evidenced the direct formation of MOF-808 
without any other phase or impurity. The integrated intensity of the $\left(\begin{array}{lll}3 & 1 & 1\end{array}\right)$ reflection was monitored as a function of crystallization time (Figure 1c), evidencing that even a slight increase in temperature from $25{ }^{\circ} \mathrm{C}$ to $40{ }^{\circ} \mathrm{C}$ induces a much faster reaction. One could therefore imagine multiplying by 5 the space-time yield by a temperature increase of $15{ }^{\circ} \mathrm{C}$ (Figure $\mathrm{S} 9$ and Table S2). The estimated Arrhenius activation energy of $34.5 \mathrm{~kJ} \cdot \mathrm{mol}^{-1}$ is in good agreement with the activation energies measured for the crystallization of other MOFs using mild temperature conditions. $^{45,46}$

As low temperature synthesis can be effective to produce nano-MOFs, ${ }^{47,48}$ our protocol with low activation energy is appealing to prepare size-controlled MOF-808 nanocrystals. Indeed, homogeneously tuning the crystal size while maintaining high product yield and quality is an interesting but still challenging topic in MOF chemistry. For example, one very recent effort with MOF-808 produced nanoparticles with low BET surface area $\left(622 \mathrm{~m}^{2} / \mathrm{g}\right)$ and poor crystallinity. ${ }^{49}$ In our case, we control the crystal size via a concentration-induced method (illustrated in Figure 2a), where the volume of water and formic acid are kept constant and the concentration of $\mathrm{Zr}_{6}$ oxoclusters and BTC linker simultaneously tuned. The MOF-808-RT synthesized with BTC concentration of $18.75 \mathrm{mg} / \mathrm{mL}$ exhibits a uniform crystal size of $850( \pm 10) \mathrm{nm}$ (labeled "850 nm MOF-808" in the following) according to scanning electron microscopy (SEM) images (Figure 2b). By increasing the concentration of reactants by 6 , the nucleation-growth kinetics of MOF808 was significantly accelerated, which shortened the synthesis time to $5 \mathrm{~h}$ in comparison to the $14 \mathrm{~h}$ for $850 \mathrm{~nm}$ MOF-808. As shown in Figure S10, PXRD patterns evidenced the high crystallinity and purity of all the materials with a progressive peak broadening (FWHM from $0.126^{\circ}$ to $0.26^{\circ}$ in $2 \theta$ ) that is consistent with the formation of nanocrystals. SEM and Highresolution transmission electron microscope (HRTEM) measurements in Figure 2b-e further 
revealed that this concentration-induced method produced well-defined cubic crystals from submicron $(850 \mathrm{~nm})$ to nanoscale $(35 \mathrm{~nm})$. These samples display very narrow size distribution with a low coefficient of variation (CV) (Figure S13). The statistical analysis also confirms the strong dependence of crystal sizes on the concentration of precursor (Figure 2f). The monodispersity of the synthesized MOF-808 could be tentatively attributed to the use of $\mathrm{Zr}_{6}$ oxoclusters as the metal source that bypasses the formation of $\mathrm{Zr}_{6}$ from $\mathrm{Zr}(\mathrm{IV})$ salts, therefore facilitating the MOFs nucleation. In addition, the syntheses were performed under stirring, which allows the reactants to be mixed in a homogeneous way. Indeed, the absence of stirring in the synthesis of $850 \mathrm{~nm}$ MOF-808 resulted not only in prolonged synthesis duration ( $>5$ days) but also in a more polydispersed sample (see Figure S14).

Additional $\mathrm{N}_{2}$ porosimetry experiments were carried out to evaluate the impact of the particle size on the surface areas and pore sizes of MOF-808. All values were consistent with the literature (Figure 2g), with only slight differences in surface areas following the relationship: $850 \mathrm{~nm}$ MOF-808 $\left(2090 \pm 17 \mathrm{~m}^{2} / \mathrm{g}\right)>210 \mathrm{~nm} \mathrm{MOF-808}(2010 \pm 20 \mathrm{~m} 2 / \mathrm{g})>60 \mathrm{~nm} \mathrm{MOF-808}$ $\left(1920 \pm 20 \mathrm{~m}^{2} / \mathrm{g}\right) \approx 35 \mathrm{~nm}$ MOF-808 $\left(1920 \pm 20 \mathrm{~m}^{2} / \mathrm{g}\right)$. The pore size distributions followed the same trend (Figure S15), 850 nm MOF-808 (18.6 ̊) > $210 \mathrm{~nm} \mathrm{MOF-808} \mathrm{(17.4} \mathrm{\AA )} \mathrm{>} 60 \mathrm{~nm}$ MOF-808 $(16.0 \AA) \approx 35 \mathrm{~nm}$ MOF-808 (16.2 $\AA$ ), which may be explained by small variation of the defect content in the structure according to the TGA (Figure S16 and Table 1). Indeed, the drop in size is accompanied by a decrease of the modulator (formic acid) to substrate ratio, which can lead to a lower number of defects, as commonly observed in $\mathrm{Zr}$ (IV)-based MOF chemistry. Owing to the very low amount of solvents used in the synthesis of $35 \mathrm{~nm} \mathrm{MOF-808}$ (1.5g MOF precursors vs $2.67 \mathrm{~mL}$ solvent) and the high reaction yield (98\%), the compound showed a gel-like feature (Figure S17) and was obtained with a high STY at $2516 \mathrm{~kg} / \mathrm{m}^{3} / \mathrm{day}$, 
suggesting possible applications in aerogels ${ }^{50,51}$ and possible up-scaling (Figure S18, synthesis of $10 \mathrm{~g}$ of $35 \mathrm{~nm}$ MOF-808 particles) of the green synthesis. To the best of our knowledge, this value is comparable to a few commercialized MOF examples, which are commonly synthesized through conventional solvothermal approaches. It should be noted that the reaction cannot be performed when the concentration of the BTC is above $112.5 \mathrm{mg} / \mathrm{mL}$ due to the very limited solvent volume that does not allow reactants be fully dispersed. 


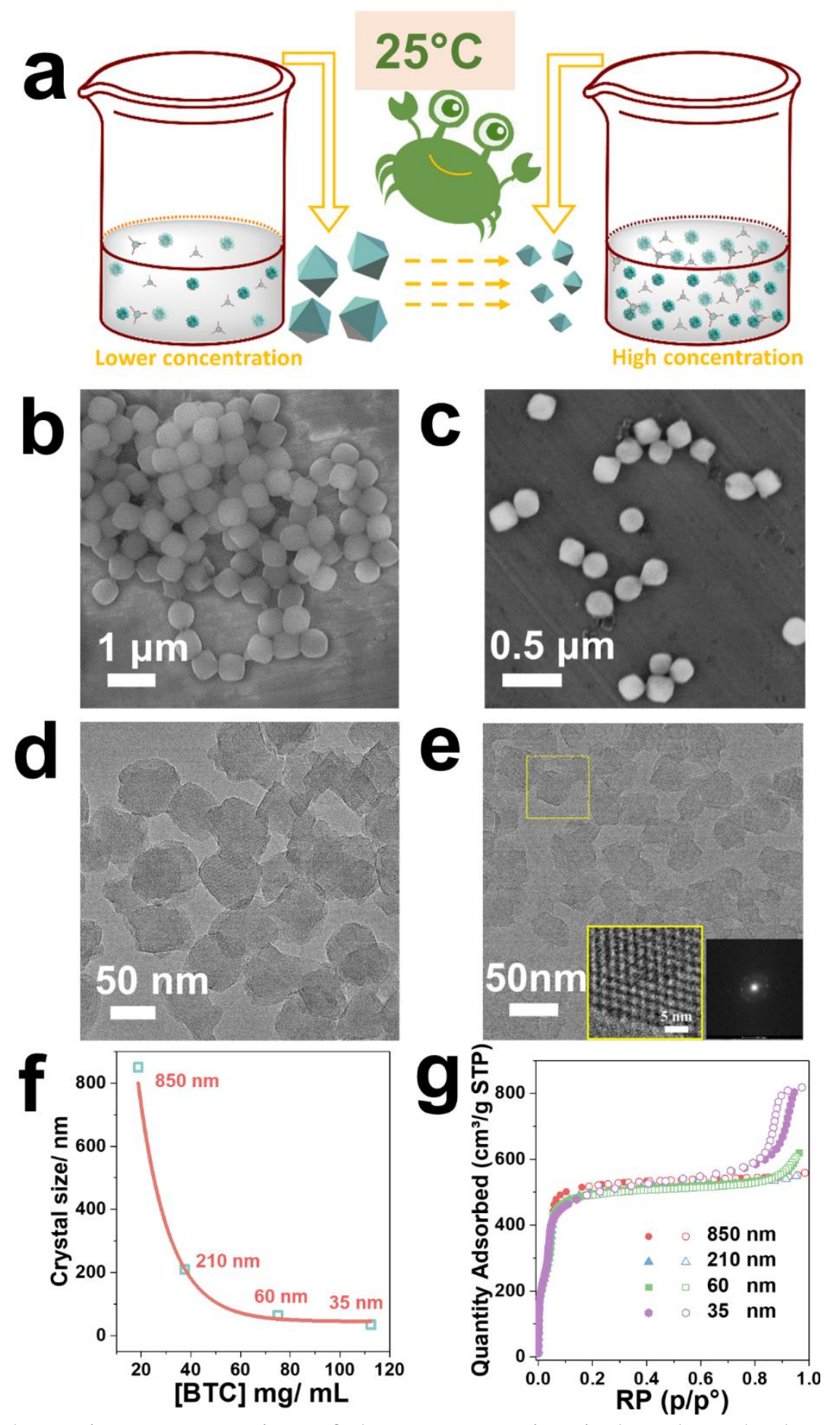

Figure 2. (a) Schematic representation of the concentration-induced method to tune the MOF808 size; SEM images of (b) $850 \mathrm{~nm}$ MOF-808 and (c) $210 \mathrm{~nm}$ MOF-808; HRTEM image of (d) $60 \mathrm{~nm}$ MOF-808, (e) $35 \mathrm{~nm}$ MOF-808, Insets: Fast Fourier transform (FFT), cropped at the predominant lattice fringes and enlarged image inside the yellow square; (f) Statistical mean size of the synthesized MOF-808 in different reactants concentrations; (g) $77 \mathrm{~K} \mathrm{~N} \mathrm{~N}_{2}$ adsorptiondesorption of $850 \mathrm{~nm}$ MOF-808, $210 \mathrm{~nm}$ MOF-808, $60 \mathrm{~nm}$ MOF-808, and $35 \mathrm{~nm}$ MOF-808, $\mathrm{RP}=$ Relative pressure. 
The size reduction might be explained by the faster reaction kinetics associated with the lower formic acid to MOF precursor ratio. It is common in MOF carboxylate chemistry to use monocarboxylic acids -called modulators- to competitively coordinate with metal sites. In such cases, the more modulator used in the synthesis, the slower the synthesis is, which usually results in larger crystals. In order to confirm this hypothesis, additional experiments were carried out. As the increase in the concentration of reactants leads to a decrease of the modulator/ reactant ratio, we changed the relative ratio between the volume of formic acid and the mass of $\mathrm{Zr}_{6}$ oxoclusters while keeping constant the concentration of reactants as in the $60 \mathrm{~nm}$ MOF-808 synthesis. For example, when this volume to mass ratio (VTMR) was 1.93 (1.93 $\mathrm{mL}$ formic acid per gram of $\mathrm{Zr}_{6}$ clusters) instead of the value 1.25 for $60 \mathrm{~nm}$ MOF-808, we observed a clear deceleration of the kinetics, confirming that the amount of modulator influences the reaction kinetics. The obtained well-crystalline product was collected and analyzed with SEM (Figure S19), evidencing the presence of $170 \mathrm{~nm}$ MOF- 808 crystals. This experiment shows that increasing the amount of modulator leads to an increase in particle size and that therefore, the concentration-induced size tuning effect is related to modulator-induced methods. As further proof, we used the parameters of the $850 \mathrm{~nm}$ MOF- 808 synthesis but decreased the VTMR to 1.93. The SEM image in Figure S20 indicated that the obtained MOF- 808 exhibited a smaller mean size of $175 \mathrm{~nm}$, very close to the MOF-808 particle size synthesized under the same VTMR but with much higher reactant concentrations. However, when the VTMR was further decreased in order to produce nano-MOF-808, a significant drop in reaction yield (12\% after 5 days with VTMR=1.1) and quality (amorphous gel) was observed. We hypothesized this might be due to solubility issues because a lower formic acid content decreases the quantity of BTC dissolved in solution as BTC has a very low solubility in pure $\mathrm{H}_{2} \mathrm{O}$ at room-temperature, 
therefore requiring a much longer synthesis duration associated with a dramatically lower yield. Notably, this can be circumvented by a slight heating (to $60^{\circ} \mathrm{C}$, see Figure S21) or addition of another organic solvent (e.g., Methanol, see Figure S22) that enhance the solubility of BTC to form smaller crystals with reasonable product yield (92\%).

Table 1. Main properties of the MOF-808 nanocrystals.

\begin{tabular}{ccccccc}
\hline $\begin{array}{c}\text { MOF-808 } \\
\text { particle } \\
\text { size }[\mathrm{nm}]\end{array}$ & $\begin{array}{c}\text { BET } \\
\begin{array}{c}\text { Surface } \\
\text { area } \\
{\left[\mathrm{m}^{2} / \mathrm{g}\right]}\end{array}\end{array}$ & $\begin{array}{c}\text { External } \\
\text { Surface } \\
\text { area } \\
{\left[\mathrm{m}^{2} / \mathrm{g}\right]^{\mathrm{a}}}\end{array}$ & $\begin{array}{c}\text { Total } \\
\text { Pore } \\
\text { volume } \\
{\left[\mathrm{cm}^{3} / \mathrm{g}\right]}\end{array}$ & $\begin{array}{c}\text { Pore size } \\
{[\AA]}\end{array}$ & Connectivity $^{\mathrm{b}}$ & $\begin{array}{c}\text { Space-time } \\
\text { yield }[\mathrm{kg} / \\
\mathrm{m}^{3} / \text { day] }\end{array}$ \\
\hline 850 & 2090 & 47 & 0.85 & 18.6 & 1.82 & 102 \\
210 & 2008 & 51 & 0.84 & 17.4 & 1.92 & 420 \\
60 & 1920 & 452 & 0.83 & 16.0 & 1.98 & 1491 \\
35 & 1920 & 775 & 0.83 & 16.2 & 1.98 & 2518 \\
\hline
\end{tabular}

${ }^{\text {a) }}$ External surface area was determined through t-plot method; ${ }^{\text {b) }}$ Connectivity refers to the bridging ligands per $\mathrm{Zr}_{6}$ oxoclusters.

NanoMOFs are suitable candidates for heterogeneous catalysis, sensing or bio-applications, ${ }^{52-54}$ mainly due to their easy processability and fast diffusion kinetics. However, when using heterogeneous catalysts in liquid phase, a high colloidal stability is required. Hence, Dynamic Light Scattering (DLS) was performed on MOF-808 in deionized water. As shown in Figure 3a (distribution in number) and Figure S23 (distribution in intensity), $35 \mathrm{~nm}$ MOF-808 displayed a constant hydrodynamic size at around $53( \pm 13) \mathrm{nm}$ and $91( \pm 27) \mathrm{nm}$, respectively, in a wide range of particle concentrations (from $0.17 \mathrm{mg} / \mathrm{mL}$ to $7 \mathrm{mg} / \mathrm{mL}, \mathrm{pH}$ from 3.63-3.82), which provided a flexible set of conditions to investigate their catalytic activity. Subsequently, timedependent DLS measurements were carried out (Figure 3b) and demonstrated the excellent dispersion stability of this nano-MOF during $24 \mathrm{~h}$ with an extremely low polydispersity index (0.05-0.1), indicating that no additive or treatment is needed to stabilize the dispersion. The 
satisfying colloidal stability and dispersion can be attributed to 1) the highly positive surface charge of the MOF-808 nanoparticles (+32 mV, Figure S24), and 2) the well-defined monodispersed nanoparticles.
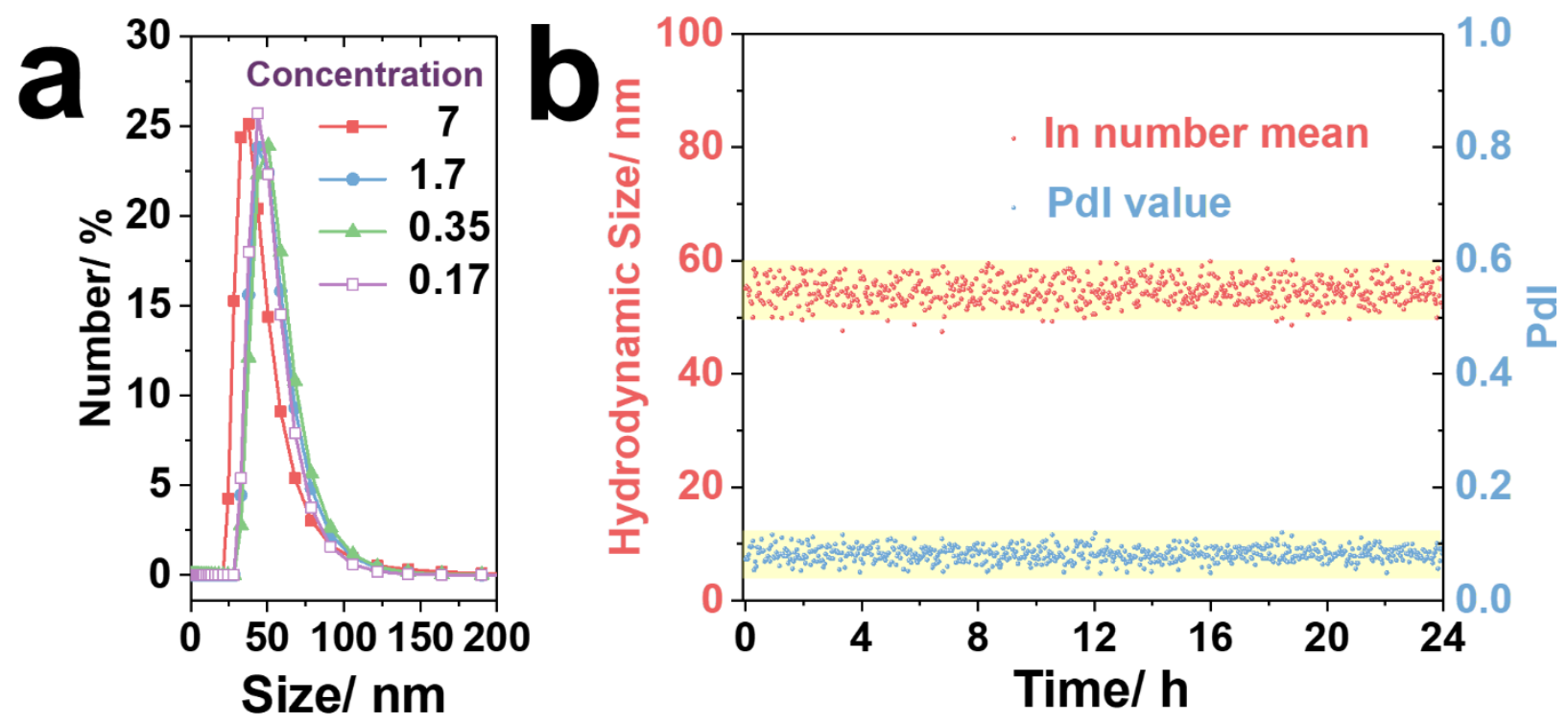

Figure 3. (a) Hydrodynamic sizes of the $35 \mathrm{~nm}$ large MOF-808 nanocrystals in aqueous solution with varying concentrations of $7,1.7,0.35,0.17 \mathrm{mg} / \mathrm{mL}$. (b) Time-resolved hydrodynamic size and polydispersity index (PdI) of the $35 \mathrm{~nm} \mathrm{MOF-808} \mathrm{in} \mathrm{aqueous} \mathrm{solution.}$

In order to investigate the effect of particle size on the catalytic activity of MOF-808, the rate of peptide bond hydrolysis at physiological $\mathrm{pH}$ was followed with both the model dipeptide glycylglycine (GG) and with the protein Hen Egg White Lysozyme (HEWL) which consists of 129 amino acids. Previous studies have shown that several $\mathrm{Zr}_{6} \mathrm{O}_{8}$-based MOFs, including MOF808 , were highly efficient catalysts for peptide bond hydrolysis. ${ }^{23}$ Conversion of GG to glycine (G) was followed by quantitative ${ }^{1} \mathrm{H}-\mathrm{NMR}$ spectroscopy over 20 h (Figure S25). Noteworthy, after $20 \mathrm{~h}$ hydrolysis the MOFs did not suffer from any significant loss of crystallinity under these reaction conditions (Figure S28). Figure 4a shows the conversion of GG with time, in 
addition to the formation of cyclic glycylglycine (cGG), consistent with previous reports involving GG and $\mathrm{Zr}_{6} \mathrm{O}_{8}$-carboxylate based MOFs. ${ }^{24,}{ }^{25}$ Hydrolysis followed first order rate kinetics (Figure S26), from which, $\mathrm{k}_{\mathrm{obs}}$ was calculated for each MOF used in the study (Figure 4b). After 20 h, $35 \mathrm{~nm}$ MOF-808 hydrolyzed 94.0\% of the GG substrate, compared with 91.3\%, $80.0 \%$ and $70.6 \%$ respectively for the 60,210 and $850 \mathrm{~nm}$ MOF-808 crystals. This resulted in $\mathrm{k}_{\mathrm{obs}}$ that ranged from $3.87 \times 10^{-5} \mathrm{~s}^{-1}$ to $1.73 \times 10^{-5} \mathrm{~s}^{-1}$ depending on the particle size (Figure $4 \mathbf{b}$ ), showing that smaller particles are the most efficient. Such differences might be due to the external surface area of the MOF. $850 \mathrm{~nm}$ MOF-808, with external surface area of $47 \mathrm{~m}^{2} / \mathrm{g}$ is significantly less efficient at peptide bond hydrolysis than $35 \mathrm{~nm}$ MOF-808, which has an external surface area of $775 \mathrm{~m}^{2} / \mathrm{g}$, while both compounds present relatively similar BET surface areas (Figure S27). This supports the notion that the hydrolysis is likely to occur on the external surface of the MOFs, as external surface area has the most significant influence on the efficiency of peptide bond hydrolysis. 


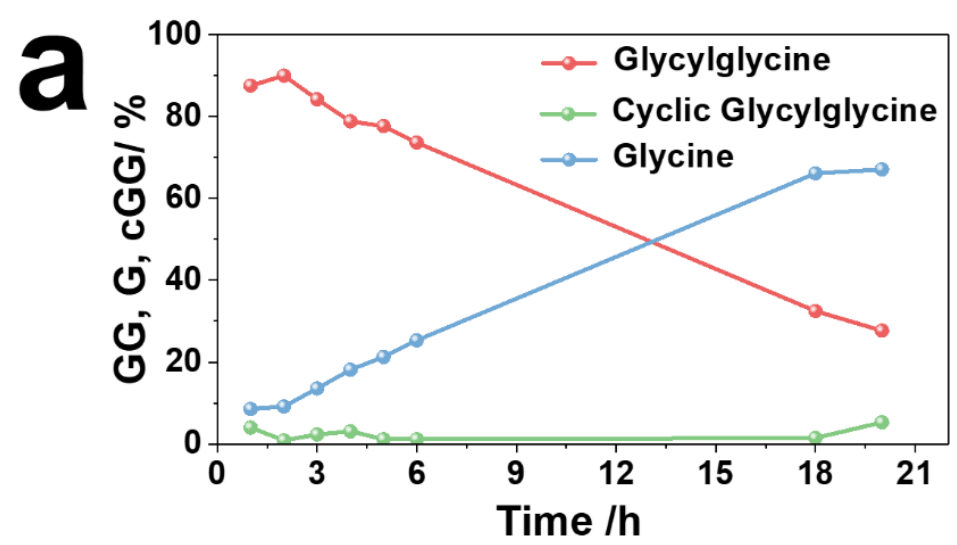

b

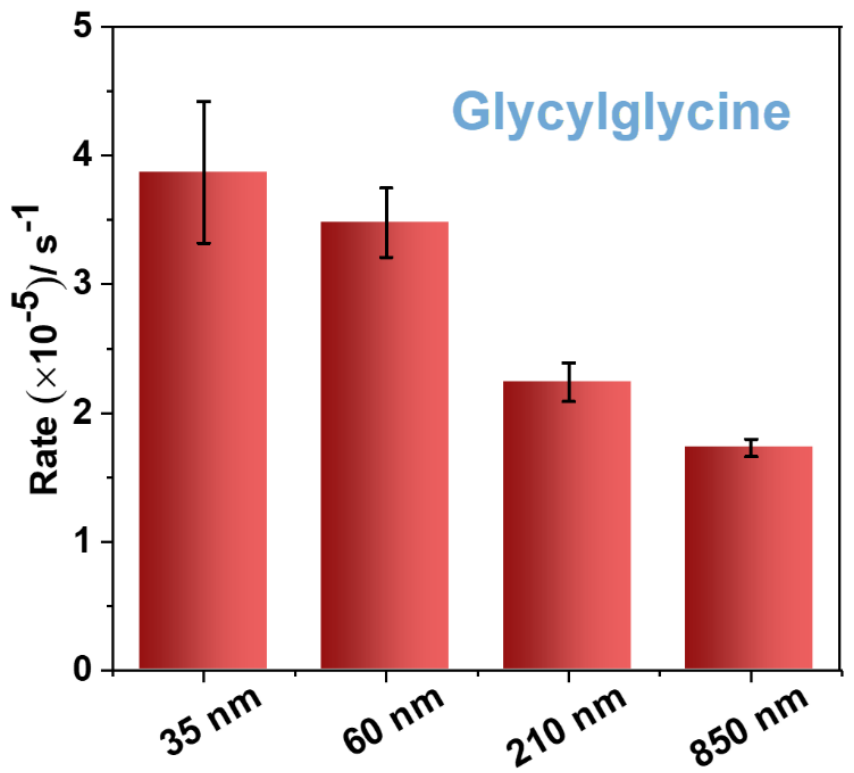

Figure 4. (a) Conversion of glycylglycine (GG) to glycine (G) and the side product cGG with time in the presence of $850 \mathrm{~nm}$ MOF-808. (b) $\mathrm{k}_{\mathrm{obs}}$ of GG hydrolysis with different MOF-808 particle sizes.

Hydrolysis of HEWL was analyzed with Coomassie stained $18 \%$ SDS-PAGE gels (Figure 5a and S29). After $72 \mathrm{~h}$ of HEWL incubation with $850 \mathrm{~nm} \mathrm{MOF-808,} \mathrm{new} \mathrm{fragments} \mathrm{appear} \mathrm{at} \mathrm{12.7,}$ $11.3,8.3,5.8$ and $4.7 \mathrm{kDa}$ in addition to the intact protein at $14.3 \mathrm{kDa}$. The four fragments with the largest molecular weight (MW) were previously observed in HEWL hydrolysis with MOF80823 and NU-1000, ${ }^{25}$ suggesting that the new MOF synthesis protocol described here does not affect the selectivity of the MOF catalysts. The MW of the fragments observed in SDS PAGE indicates that they are most likely generated through hydrolysis of the peptide bonds at Asp18 
(12.7 kDa), Asp52 (8.3 kDa), and Asp66 (5.8 kDa), as well as sequential hydrolysis of the 12.7 $\mathrm{kDa}$ fragment at Asp 119, to give the $11.3 \mathrm{kDa}$ fragment, in analogy with the previously reported HEWL hydrolysis by metal complexes. ${ }^{51}$ The lightest fragment $(4.7 \mathrm{kDa})$ was not observed before in MOF catalyzed hydrolysis of HEWL but it corresponds well to the MW of a fragment previously observed in HEWL hydrolysis by an Hf(IV)-Polyoxometalate, ${ }^{55}$ resulting from hydrolysis at the Asp101 site. In addition to these 6 Asp residues, there are two additional Asp residues in HEWL (Asp48 and Asp87) that are located on short stretches of random coils in between larger regions of secondary structure (Figure S30). They most likely remain buried in the tertiary structure of the protein and as such are unaccessible to the active metal sites of the MOF even after partial hydrolysis of the intact protein. The rate of peptide bond hydrolysis in HEWL showed the same trend as with GG hydrolysis, with an increase in the rate observed as particle size decreases (Figure 5b).
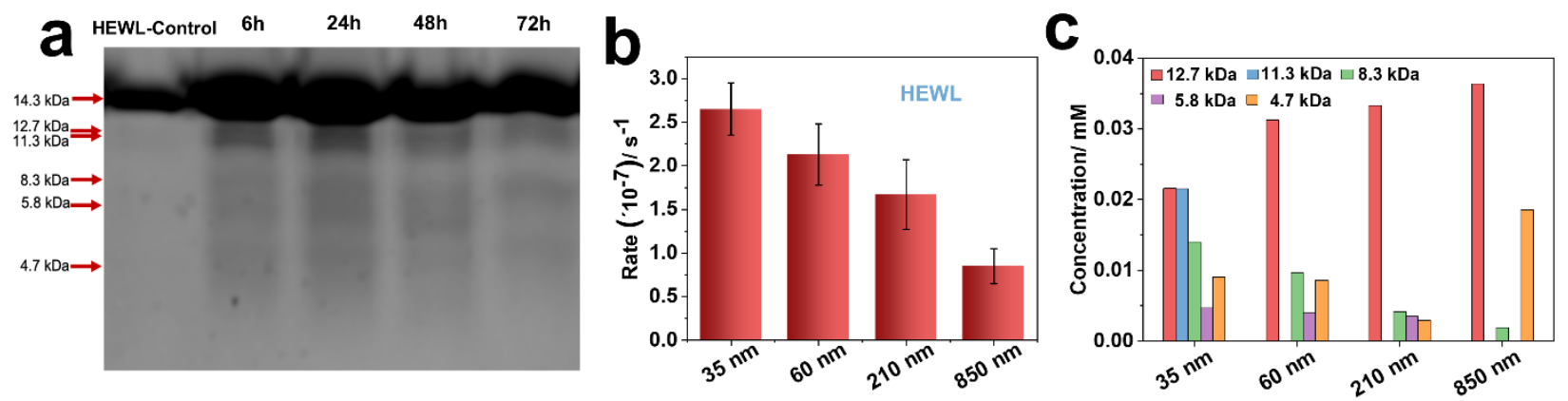

Figure 5. (a) Hydrolysis of HEWL by $850 \mathrm{~nm}$ MOF-808 followed by Coomassie blue stained SDS-PAGE. Native weight of protein - $14.3 \mathrm{kDa}$ (b) $\mathrm{k}_{\text {obs }}$ of HEWL hydrolysis with all MOFs. (c) Concentration of HEWL hydrolysis fragments after $72 \mathrm{~h}$ incubation with all MOFs, from SDS-PAGE band analysis.

In addition, as demonstrated in Figure 5c, the number of resulting polypeptide fragments and their concentration can be tuned by changing the MOF particle size. While MOFs with smaller particle size produce more fragments within comparable range of concentrations, the larger particle sizes appear to be more efficient at hydrolyzing the Asp18 site, and show limited 
hydrolysis at Asp52 and Asp66 residues. Furthermore, these MOFs exhibited higher activity towards the secondary hydrolysis at the Asp119 site, which resulted in higher concentration of the lightest fragment at $4.7 \mathrm{kDa}$. With $35 \mathrm{~nm} \mathrm{MOF-808,} \mathrm{the} \mathrm{fragment} \mathrm{coming} \mathrm{from} \mathrm{the}$ hydrolysis at Asp18 bond is likely further hydrolyzed at Asp119 to give the $11.3 \mathrm{kDa}$ fragment, which has not been detected for other MOFs. Taking into account the dimensions of HEWL (35 x 25 x $45 \AA$ ), it is unlikely that the protein is able to diffuse into the MOFs pores without some degree of unfolding as the maximum pore size is $18.6 \AA$. Such unfolding has been reported previously for the incorporation of the smaller cytochrome c protein into NU-1000 and Tb-meso MOF. ${ }^{56,57}$ Therefore, we propose that the initial hydrolysis occurs on the surface exposed $\mathrm{Zr}$ nodes present within the half-spherical pockets on the surface of particles that are of similar size to HEWL, after which, subsequent hydrolysis of smaller fragments may also occur to a limited extent, within the pores, as the parent fragments are small enough to diffuse through the pore windows. ${ }^{23}$ As was proposed for GG hydrolysis, the external surface area of the MOFs contributes significantly to the observed hydrolysis patterns. For $210 \mathrm{~nm}$ MOF-808 and $850 \mathrm{~nm}$ MOF-808, which have similar external surface areas (51 and $47 \mathrm{~m}^{2} / \mathrm{g}$ respectively) the hydrolysis patterns are similar, with the major HEWL fragment being $12.7 \mathrm{kDa}$. However, as the external surface area increases to $775 \mathrm{~m}^{2} / \mathrm{g}$ for $35 \mathrm{~nm}$ MOF-808, the efficiency of HEWL hydrolysis and number of resulting fragments increase in line with the increase in number of active metal sites present on the external surface of the MOF. The more efficient protein hydrolysis could also be due to the more effective MOF-protein interaction on the structure of the protein as smaller size nanoMOFs with a significantly larger external surface area may induce a substantial structural change in HEWL, causing a greater degree of protein unfolding over the surface of the 
nanoMOF. This in turn may expose more Asp residues to come into contact with the active metal sites, promoting hydrolysis at more sites on the protein surface.

\section{Conclusion}

This article reports for the first time an efficient room-temperature synthesis of the benchmark 6-connected MOF-808 under environmentally-friendly conditions. The novel synthesis conditions allowed us to achieve a size tuning from sub-micron range $(850 \mathrm{~nm})$ to the nanoscale $(35 \mathrm{~nm})$ while maintaining high crystallinity, porosity, homogeneity and a high space-time yield. In addition, we showed the high quality of the colloidal dispersion of the nano-MOF-808, reaching a nearly monodispersed suspension both at various concentrations (from $7 \mathrm{mg} / \mathrm{mL}$ to $0.17 \mathrm{mg} / \mathrm{mL}$ ) and long-time-scale (24h). Such ambient conditions are particularly appealing for the incorporation of temperature sensitive species (e.g. small nanoparticles, enzymes, etc.) inside MOFs. Subsequently, the nano-MOF-808 exhibited a remarkable size-dependent catalytic efficiency towards a challenging peptide bond hydrolysis, with the smallest nanoMOF showing the highest catalytic potential. The trend is directly proportional to the external surface area of the MOF particles, thus suggesting that the catalytic reaction is likely to occur on the MOF external surface. The nanoMOF-808 was also able to selectively hydrolyze HEWL protein, efficiently producing fragments with MW that are suitable for the analysis in the emerging middle-down proteomics applications. Additionally, varying the particle size gives control over the specific protein fragments produced. This shows that MOFs can be synthesized with a specific particle size to produce desired fragments, proving these MOFs can act as superior artificial protease nanozymes for use in the field of proteomics. Finally, we hope this work 
can pave the way for efficient heterogeneous catalysis applications but also for applications

that require colloidal-level nano-MOF-808.

\section{Supporting Information}

Additional synthetic details, PXRD, MS, EDX, TGA, In-situ PXRD, and SEM data (PDF)

\section{Acknowledgements}

S. D. is grateful for the support from CSC grant (grant number 201706140196). S.D. appreciates the helpful discussion with Sujing Wang (USTC). C. Simms thanks Research Foundation Flanders (FWO) for doctoral fellowship (11C9320N). T.N.P.V. thanks F.W.O. for funding (G095017N). DIM Respore is acknowledged for the access to HRTEM. Joelle Vinh and Giovanni Chiappetta are acknowledged for MS.

\section{References}

1. Shang, L.; Nienhaus, K.; Nienhaus, G. U., Engineered nanoparticles interacting with cells: size matters. J. Nanobiotechnology 2014, 12, 1-11.

2. Jain, P. K.; Huang, X. H.; El-Sayed, I. H.; El-Sayed, M. A., Noble Metals on the Nanoscale: Optical and Photothermal Properties and Some Applications in Imaging, Sensing, Biology, and Medicine. Acc. Chem. Res. 2008, 41 (12), 1578-1586.

3. Cao, S.; Tao, F. F.; Tang, Y.; Li, Y.; Yu, J., Size- and shape-dependent catalytic performances of oxidation and reduction reactions on nanocatalysts. Chem. Soc. Rev. 2016, 45 (17), 4747-65.

4. Simon-Yarza, T.; Mielcarek, A.; Couvreur, P.; Serre, C., Nanoparticles of Metal-Organic Frameworks: On the Road to In Vivo Efficacy in Biomedicine. Adv. Mater. 2018, 30 (37), 1707365. 
5. Xiao, X.; Zou, L. L.; Pang, H.; Xu, Q., Synthesis of micro/nanoscaled metal-organic frameworks and their direct electrochemical applications. Chem. Soc. Rev. 2020, 49 (1), 301-331.

6. Sindoro, M.; Yanai, N.; Jee, A. Y.; Granick, S., Colloidal-Sized Metal-Organic Frameworks: Synthesis and Applications. Acc. Chem. Res. 2014, 47 (2), 459-469.

7. Dang, S.; Zhu, Q. L.; Xu, Q., Nanomaterials derived from metal-organic frameworks. Nat. Rev. Mater. 2018, 3 (1), 1-14.

8. Bachman, J. E.; Smith, Z. P.; Li, T.; Xu, T.; Long, J. R., Enhanced ethylene separation and plasticization resistance in polymer membranes incorporating metal-organic framework nanocrystals. Nat. Mater. 2016, 15 (8), 845-849.

9. Sakata, Y.; Furukawa, S.; Kondo, M.; Hirai, K.; Horike, N.; Takashima, Y.; Uehara, H.; Louvain, N.; Meilikhov, M.; Tsuruoka, T.; Isoda, S.; Kosaka, W.; Sakata, O.; Kitagawa, S., Shape-Memory Nanopores Induced in Coordination Frameworks by Crystal Downsizing. Science 2013, 339 (6116), 193-196.

10. Doherty, C. M.; Buso, D.; Hill, A. J.; Furukawa, S.; Kitagawa, S.; Falcaro, P., Using Functional Nano- and Microparticles for the Preparation of Metal-Organic Framework Composites with Novel Properties. Acc. Chem. Res. 2014, 47 (2), 396-405.

11. Aguado, S.; Canivet, J.; Farrusseng, D., Engineering structured MOF at nano and macroscales for catalysis and separation. J. Mater. Chem. 2011, 21 (21), 7582-7588.

12. Khan, N. A.; Kang, I. J.; Seok, H. Y.; Jhung, S. H., Facile synthesis of nano-sized metalorganic frameworks, chromium-benzenedicarboxylate, MIL-101. Chem. Eng. J. 2011, 166 (3), $1152-1157$. 
13. Morris, W.; Wang, S. Z.; Cho, D.; Auyeung, E.; Li, P.; Farha, O. K.; Mirkin, C. A., Role of Modulators in Controlling the Colloidal Stability and Polydispersity of the UiO-66 Metal-Organic Framework. Acs Appl. Mater. \& Interfaces 2017, 9 (39), 33413-33418.

14. Zhang, A. J.; Li, X. Y.; Zhang, S. Y.; Yu, Z. K.; Gao, X. M.; Wei, X. R.; Wu, Z. X.; Wu, W. D.; Chen, X. D., Spray-drying-assisted reassembly of uniform and large micro-sized MIL-101 microparticles with controllable morphologies for benzene adsorption. J. Colloid and Interface Sci. 2017, 506, 1-9.

15. Majewski, M. B.; Noh, H.; Islamoglu, T.; Farha, O. K., NanoMOFs: little crystallites for substantial applications. J. Mater. Chem. A 2018, 6 (17), 7338-7350.

16. Wang, S.; McGuirk, C. M.; d'Aquino, A.; Mason, J. A.; Mirkin, C. A., Metal-Organic Framework Nanoparticles. Adv. Mater. 2018, 30 (37), 1800202.

17. Radzicka, A.; Wolfenden, R., Rates of uncatalyzed peptide bond hydrolysis in neutral solution and the transition state affinities of proteases. J. Am. Chem. Soc. 1996, 118 (26), 61056109.

18. Clearfield, A., THE MECHANISM OF HYDROLYTIC POLYMERIZATION OF ZIRCONYL SOLUTIONS. J. Mater. Res. 1990, 5 (1), 161-162.

19. Yashiro, M.; Takarada, T.; Miyama, S.; Komiyama, M., CERIUM(IV)CYCLODEXTRIN COMPLEX FOR PEPTIDE HYDROLYSIS IN NEUTRAL HOMOGEnEOUS SOLUTIONS. J. Chem. Soc., Chem. Commun. 1994, (15), 1757-1758. 
20. Milinkovic, S. U.; Parac, T. N.; Djuran, M. I.; Kostic, N. M., Dependence of hydrolytic cleavage of histidine-containing peptides by palladium(II) aqua complexes on the co-ordination modes of the peptides. J. Chem. Soc., Dalton Trans. 1997, (16), 2771-2776.

21. Kopera, E.; Krezel, A.; Protas, A. M.; Belczyk, A.; Bonna, A.; Wyslouch-Cieszynska, A.; Poznanski, J.; Bal, W., Sequence-Specific Ni(II)-Dependent Peptide Bond Hydrolysis for Protein Engineering: Reaction Conditions and Molecular Mechanism. Inorg. Chem. 2010, 49 (14), 6636-6645.

22. Krezel, A.; Kopera, E.; Protas, A. M.; Poznanski, J.; Wyslouch-Cieszynska, A.; Bal, W., Sequence-Specific Ni(II)-Dependent Peptide Bond Hydrolysis for Protein Engineering. Combinatorial Library Determination of Optimal Sequences. J. Am. Chem. Soc. 2010, 132 (10), 3355-3366.

23. Ly, H. G. T.; Fu, G. X.; Kondinski, A.; Bueken, B.; De Vos, D.; Parac-Vogt, T. N., Superactivity of MOF-808 toward Peptide Bond Hydrolysis. J. Am. Chem. Soc. 2018, 140 (20), $6325-6335$.

24. Ly, H. G. T.; Fu, G. X.; de Azambuja, F.; De Vos, D.; Parac-Vogt, T. N., Nanozymatic Activity of UiO-66 Metal-Organic Frameworks: Tuning the Nanopore Environment Enhances Hydrolytic Activity toward Peptide Bonds. Acs Appl. Mater. \& Interfaces 2020, 3 (9), 89318938.

25. Loosen, A.; de Azambuja, F.; Smolders, S.; Moons, J.; Simms, C.; De Vos, D.; ParacVogt, T. N., Interplay between structural parameters and reactivity of Zr-6-based MOFs as artificial proteases. Chem. Sci. 2020, 11 (26), 6662-6669. 
26. Bai, Y.; Dou, Y. B.; Xie, L. H.; Rutledge, W.; Li, J. R.; Zhou, H. C., Zr-based metalorganic frameworks: design, synthesis, structure, and applications. Chem. Soc. Rev. 2016, 45 (8), $2327-2367$.

27. Cavka, J. H.; Jakobsen, S.; Olsbye, U.; Guillou, N.; Lamberti, C.; Bordiga, S.; Lillerud, K. P., A new zirconium inorganic building brick forming metal organic frameworks with exceptional stability. J. Am. Chem. Soc. 2008, 130 (42), 13850-13851.

28. Wu, H.; Chua, Y. S.; Krungleviciute, V.; Tyagi, M.; Chen, P.; Yildirim, T.; Zhou, W., Unusual and Highly Tunable Missing-Linker Defects in Zirconium Metal-Organic Framework UiO-66 and Their Important Effects on Gas Adsorption. J. Am. Chem. Soc. 2013, 135 (28), $10525-10532$.

29. Vermoortele, F.; Bueken, B.; Le Bars, G.; Van de Voorde, B.; Vandichel, M.; Houthoofd, K.; Vimont, A.; Daturi, M.; Waroquier, M.; Van Speybroeck, V.; Kirschhock, C.; De Vos, D. E., Synthesis Modulation as a Tool To Increase the Catalytic Activity of MetalOrganic Frameworks: The Unique Case of UiO-66(Zr). J. Am. Chem. Soc. 2013, 135 (31), $11465-11468$.

30. Furukawa, H.; Gandara, F.; Zhang, Y. B.; Jiang, J. C.; Queen, W. L.; Hudson, M. R.; Yaghi, O. M., Water Adsorption in Porous Metal-Organic Frameworks and Related Materials. J. Am. Chem. Soc. 2014, $136(11), 4369-4381$.

31. Moon, S. Y.; Liu, Y. Y.; Hupp, J. T.; Farha, O. K., Instantaneous Hydrolysis of NerveAgent Simulants with a Six-Connected Zirconium-Based Metal-Organic Framework. Angew. Chem. Int. Ed. 2015, 54 (23), 6795-6799. 
32. Trickett, C. A.; Popp, T. M. O.; Su, J.; Yan, C.; Weisberg, J.; Huq, A.; Urban, P.; Jiang, J. C.; Kalmutzki, M. J.; Liu, Q. N.; Baek, J.; Head-Gordon, M. P.; Somorjai, G. A.; Reimer, J. A.; Yaghi, O. M., Identification of the strong Bronsted acid site in a metal-organic framework solid acid catalyst. Nat. Chem. 2019, 11 (2), 170-176.

33. Osterrieth, J. W. M.; Wright, D.; Noh, H.; Kung, C. W.; Vulpe, D.; Li, A.; Park, J. E.; Van Duyne, R. P.; Moghadam, P. Z.; Baumberg, J. J.; Farha, O. K.; Fairen-Jimenez, D., CoreShell Gold Nanorod@Zirconium-Based Metal-Organic Framework Composites as in Situ SizeSelective Raman Probes. J. Am. Chem. Soc. 2019, 141 (9), 3893-3900.

34. Lu, G.; Li, S. Z.; Guo, Z.; Farha, O. K.; Hauser, B. G.; Qi, X. Y.; Wang, Y.; Wang, X.; Han, S. Y.; Liu, X. G.; DuChene, J. S.; Zhang, H.; Zhang, Q. C.; Chen, X. D.; Ma, J.; Loo, S. C. J.; Wei, W. D.; Yang, Y. H.; Hupp, J. T.; Huo, F. W., Imparting functionality to a metalorganic framework material by controlled nanoparticle encapsulation. Nat. Chem. 2012, 4 (4), 310-316.

35. Guillerm, V.; Gross, S.; Serre, C.; Devic, T.; Bauer, M.; Ferey, G., A zirconium methacrylate oxocluster as precursor for the low-temperature synthesis of porous zirconium(IV) dicarboxylates. Chem. Commun. 2010, 46 (5), 767-769.

36. DeStefano, M. R.; Islamoglu, T.; Hupp, J. T.; Farha, O. K., Room-Temperature Synthesis of UiO-66 and Thermal Modulation of Densities of Defect Sites. Chem. Mat. 2017, 29 (3), 1357-1361.

37. Sang, X.; Zhang, J.; Xiang, J.; Cui, J.; Zheng, L.; Zhang, J.; Wu, Z.; Li, Z.; Mo, G.; Xu, Y.; Song, J.; Liu, C.; Tan, X.; Luo, T.; Zhang, B.; Han, B., Ionic liquid accelerates the crystallization of Zr-based metal-organic frameworks. Nat. Commun. 2017, 8 (1), 1-7. 
38. Avci-Camur, C.; Perez-Carvajal, J.; Imaz, I.; Maspoch, D., Metal Acetylacetonates as a Source of Metals for Aqueous Synthesis of Metal-Organic Frameworks. ACS Sustain. Chem. Eng. 2018, 6 (11), 14554-14560.

39. Pakamorè, I.; Rousseau, J.; Rousseau, C.; Monflier, E.; Szilágyi, P. Á., An ambienttemperature aqueous synthesis of zirconium-based metal-organic frameworks. Green Chem. 2018, 20 (23), 5292-5298.

40. Noh, H.; Kung, C.-W.; Islamoglu, T.; Peters, A. W.; Liao, Y.; Li, P.; Garibay, S. J.; Zhang, X.; DeStefano, M. R.; Hupp, J. T.; Farha, O. K., Room Temperature Synthesis of an 8Connected Zr-Based Metal-Organic Framework for Top-Down Nanoparticle Encapsulation. Chem. Mat. 2018, 30 (7), 2193-2197.

41. Dai, S.; Nouar, F.; Zhang, S.; Tissot, A.; Serre, C., One-Step Room-Temperature Synthesis of Metal(IV) Carboxylate Metal-Organic Frameworks. Angew. Chem. Int. Ed. 2021, 60 (8), 4282-4288.

42. Jiang, J. C.; Gandara, F.; Zhang, Y. B.; Na, K.; Yaghi, O. M.; Klemperer, W. G., Superacidity in Sulfated Metal-Organic Framework-808. J. Am. Chem. Soc. 2014, 136 (37), 12844-12847.

43. Ragon, F.; Horcajada, P.; Chevreau, H.; Hwang, Y. K.; Lee, U. H.; Miller, S. R.; Devic, T.; Chang, J. S.; Serre, C., In Situ Energy-Dispersive X-ray Diffraction for the Synthesis Optimization and Scale-up of the Porous Zirconium Terephthalate UiO-66. Inorg. Chem. 2014, $53(5), 2491-2500$. 
44. Millange, F.; Serre, C.; Guillou, N.; Ferey, G.; Walton, R. I., Structural effects of solvents on the breathing of metal-organic frameworks: An in situ diffraction study. Angew. Chem. Int. Ed. 2008, 47 (22), 4100-4105.

45. Haque, E.; Khan, N. A.; Park, J. H.; Jhung, S. H., Synthesis of a metal-organic framework material, iron terephthalate, by ultrasound, microwave, and conventional electric heating: a kinetic study. Chemistry 2010, 16 (3), 1046-1052.

46. Zahn, G.; Zerner, P.; Lippke, J.; Kempf, F. L.; Lilienthal, S.; Schröder, C. A.; Schneider, A. M.; Behrens, P., Insight into the mechanism of modulated syntheses: in situ synchrotron diffraction studies on the formation of Zr-fumarate MOF. CrystEngComm 2014, 16 (39), 9198-9207.

47. Xia, W.; Zhu, J. H.; Guo, W. H.; An, L.; Xia, D. G.; Zou, R. Q., Well-defined carbon polyhedrons prepared from nano metal-organic frameworks for oxygen reduction. J. Mater. Chem. A 2014, 2 (30), 11606-11613.

48. Chalati, T.; Horcajada, P.; Gref, R.; Couvreur, P.; Serre, C., Optimisation of the synthesis of MOF nanoparticles made of flexible porous iron fumarate MIL-88A. J. Mater. Chem. 2011, 21 (7), 2220-2227.

49. Thur, R.; Van Velthoven, N.; Lemmens, V.; Bastin, M.; Smolders, S.; De Vos, D.; Vankelecom, I. F. J., Modulator-Mediated Functionalization of MOF-808 as a Platform Tool to Create High-Performance Mixed-Matrix Membranes. ACS Appl. Mater. Interfaces 2019, 11 (47), $44792-44801$. 
50. Li, L.; Xiang, S.; Cao, S.; Zhang, J.; Ouyang, G.; Chen, L.; Su, C. Y., A synthetic route to ultralight hierarchically micro/mesoporous $\mathrm{Al}(\mathrm{III})$-carboxylate metal-organic aerogels. Nat. Commun. 2013, 4, 1-9.

51. Xia, W.; Zhang, X.; Xu, L.; Wang, Y.; Lin, J.; Zou, R., Facile and economical synthesis of metal-organic framework MIL-100(Al) gels for high efficiency removal of microcystin-LR. RSC Adv. 2013, 3 (27), 11007-11013.

52. Cai, X.; Xie, Z.; Li, D.; Kassymova, M.; Zang, S.-Q.; Jiang, H.-L., Nano-sized metalorganic frameworks: Synthesis and applications. Coord. Chem. Rev. 2020, 417, 213366.

53. Marshall, C. R.; Staudhammer, S. A.; Brozek, C. K., Size control over metal-organic framework porous nanocrystals. Chem. Sci. 2019, 10 (41), 9396-9408.

54. Dalstein, O.; Gkaniatsou, E.; Sicard, C.; Sel, O.; Perrot, H.; Serre, C.; Boissiere, C.; Faustini, M., Evaporation-Directed Crack-Patterning of Metal-Organic Framework Colloidal Films and Their Application as Photonic Sensors. Angew. Chem. Int. Ed. 2017, 56 (45), 1401114015.

55. Vandebroek, L.; De Zitter, E.; Ly, H. G. T.; Conic, D.; Mihaylov, T.; Sap, A.; Proost, P.; Pierloot, K.; Van Meervelt, L.; Parac-Vogt, T. N., Protein-Assisted Formation and Stabilization of Catalytically Active Polyoxometalate Species. Chem. Eur. J. 2018, 24 (40), 10099-10108.

56. Chen, Y.; Lykourinou, V.; Vetromile, C.; Hoang, T.; Ming, L. J.; Larsen, R. W.; Ma, S. Q., How Can Proteins Enter the Interior of a MOF? Investigation of Cytochrome c Translocation 
into a MOF Consisting of Mesoporous Cages with Microporous Windows. J. Am. Chem. Soc. 2012, 134 (32), 13188-13191.

57. Chen, Y.; Jimenez-Angeles, F.; Qiao, B.; Krzyaniak, M. D.; Sha, F.; Kato, S.; Gong, X.; Buru, C. T.; Chen, Z.; Zhang, X.; Gianneschi, N. C.; Wasielewski, M. R.; Olvera de la Cruz, M.; Farha, O. K., Insights into the Enhanced Catalytic Activity of Cytochrome c When Encapsulated in a Metal-Organic Framework. J. Am. Chem. Soc. 2020, 142(43), 18576-18582. 